\title{
CollegeNews
}

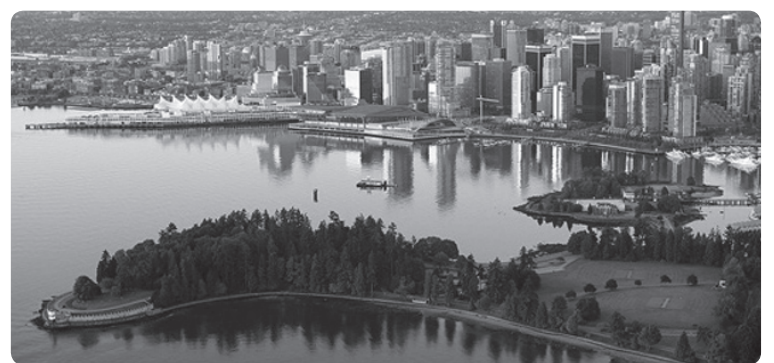

Annual Clinical Genetics Meeting Program information now available at www.acmgmeeting.net.

The 2011 Annual Clinical Genetics Meeting in Vancouver British Columbia is just around the corner. Be sure to visit www.acmgmeeting.net where you can register online and make hotel reservations. See below for can't-miss deadlines and important travel information.

\section{ABSTRACT SUBMISSION}

Abstract submission for the 2011 Annual Clinical Genetics Meeting is now closed.

\section{REGISTRATION}

Advance discounted registration fees will be available through February 9, 2011. After February 10, on-site registration fees will apply. Register now at www.acmgmeeting.net to lock in your discounted registration rate.

\section{HOTEL RESERVATIONS}

Registration for the meeting is required prior to making hotel reservations. All reservations for the 2011 ACMG Annual Clinical Genetics Meeting must be booked through the ACMG Housing Bureau - onPeak. If you have not yet registered or made hotel reservations, at the conclusion of the registration process there will be a direct link to make your hotel reservations. If you do not reserve your hotel at the time of registration, a hotel access code will be provided in your registration confirmation that can be utilized to make hotel reservations at a separate time.

For more information on hotels and the hotel reservation process and inquiries regarding hotel availability please contact the ACMG's Housing Partner - onPeak at acmg@onpeakevents.com.

\section{TRAVEL AND PASSPORT INFORMATION}

Travel to Canada: Those planning on attending the meeting are reminded that all travelers, including U.S. and Canadian citizens, are required to have a passport or other accepted form of documentation to enter or depart the United States. The ACMG Meeting website contains detailed information on renewing or applying for a passport, the countries and territories whose citizens require visas in order to enter Canada and other helpful information. Go to www. acmgmeeting.net and click on Attendee Information/ Passport \& Customs Information to learn more.

\section{SESSION HIGHLIGHTS}

The detailed program schedule and speakers can be found at www.acmgmeeting.net in the Program Sessions and Events Schedule section of the website. Attendees can view the schedule overall or plan their session itinerary online.

\section{Plenary sessions include:}

2011 Presidential Plenary that will include "The State of ACMG" and two scientific presentations: Translational Genomics and Health Outcomes; and Update on the NIH's Genetic Testing Registry.

42nd Annual March of Dimes Clinical Genetics Conference: Hereditary Disorders of Connective Tissue: Update 2011

Highlights Plenary Session: The Exome Strategy for Gene Discovery and Medical Practice

Closing Plenary Session: Delivering Genomic Testing Results to Patients 
In addition to a Special Satellite Session-Community Conversation with First Nations: Genetics Issues and Native Populations to be held on Wednesday evening-other invited sessions throughout the meeting will focus on topics such as Newborn Screening, Cardinal Signs of Select Genetic Syndromes and Rare Inborn Errors of Metabolism, Neoplastic Disorders, Disorders of Sex Development, Constitutional Mosaicism, Genomic Medicine in the Prevention of Cancer, Global Perspectives on Screening for Jewish Genetic Diseases among many others.

Be sure to visit www.acmgmeeting.net for the list of pre-conference CME Courses, Industry Supported Symposia and other educational opportunities to be offered at the 2011 ACMG Annual Clinical Genetics Meeting in Vancouver.

\section{Summer Genetics Scholars Program}

According to the Royal College of Physicians in the United Kingdom, there should be one fulltime equivalent (FTE) clinical geneticist per 250,000 citizens. Following the most recent certification cycle in the United States, there is currently only one FTE clinical geneticist per approximately 608,000 Americans - less than half of the minimum needed to serve this country adequately!

To address this critical workforce issue, the 2011 ACMG Foundation Summer Genetics Scholars Program (SGSP) will introduce rising second year medical students to the most diverse and exciting field in medicine today-medical genetics. SGSP will foster professional mentorships and highlight the many diverse employment opportunities within the field. For more information on being an SGSP mentor, please contact KC Ellis, Kellis@acmg.net or 301-718-2014, at the ACMG Foundation.

\section{Deadline Approaching! You're Invited...to Help Celebrate ACMG's 20th Anniversary}

The College is celebrating its 20th anniversary in 2011. Many activities are planned for the year to commemorate the progress made in the past 20 years and also to look forward to the future. Part of the celebration will include a special 20th Anniversary Edition of Genetics in Medicine in March 2011. Members are invited to send letters to GIM for possible inclusion in this commemorative edition. Please share your memories of the field of genetic medicine, the annual meetings, the early years, humorous stories or anything else that can help to commemorate the past 20 years. Submissions can be of any length.

Please send your letters, stories and comments to the journal through its website at: http://www.editorialmanager.com/gim using the "Letter to the Editor" category and clearly marking in the comments box that they are to be considered for the 20th Anniversary Issue in March 2011.

\section{ACMG Genetics Review Course}

The next Genetics Review Course will be held June 2-5, 2011 at the Hilton DFW Lakes Executive Conference Center in Grapevine, Texas. Program, registration and hotel information now available. Visit www.acmg.net for full details. 